\title{
Transport and Metabolism of Bacilysin and Other Peptides by Suspensions of Staphylococcus aureus
}

\author{
By DAVID PERRY AND E. P. ABRAHAM \\ Sir William Dunn School of Pathology, University of Oxford, Oxford OX13RE
}

(Received 5 February 1979)

\begin{abstract}
L-Alanyl-L-tyrosine and glycyl-L-phenylalanine labelled with ${ }^{14} \mathrm{C}$ competed with each other and with the dipeptide antibiotic bacilysin for transport into Staphylococcus aureus NCTC 6571 in a medium which did not support growth. They also competed with other dipeptides and several tripeptides. The fast initial transport of the two labelled peptides appeared to show Michaelis-Menten kinetics. Neither was transported into a bacilysin-resistant mutant of $S$. aureus NCTC 6571, although tyrosine was taken up by the mutant as readily as it was by the parent strain.

Uptake of alanyltyrosine or glycylphenylalanine was followed by rapid hydrolysis of the peptide and the excretion of tyrosine or phenylalanine. Glycine liberated from glycylphenylalanine was partly degraded and partly incorporated into the bacterial wall. The behaviour of these dipeptides paralleled the inactivation of bacilysin by suspensions of $S$. aureus and the appearance of its C-terminal amino acid, anticapsin, in the extracellular fluid.
\end{abstract}

\section{INTRODUCTION}

Bacilysin, a dipeptide antibiotic produced by Bacillus subtilis A14 has the structure I (Walker \& Abraham, 1970). The C-terminal amino acid of bacilysin, anticapsin, is also produced by B. subtilis A14 (Walker \& Abraham, 1970) and by Streptomyces griseoplanus NRRL 3507 (Neuss et al., 1970). Kenig \& Abraham (1976) reported evidence for the view that the antibacterial activity of bacilysin depended on its transport into bacteria as a dipeptide and that bacilysin-resistant mutants of Staphylococcus aureus were defective in a peptide transport system. Kenig et al. (1976) showed that the transport of bacilysin into sensitive bacteria was followed by enzymic hydrolysis to yield anticapsin, which inhibited glucosamine synthesis.

This paper describes more direct experiments on the transport of peptides into $S$. aureus and on their subsequent fate. Earlier reports of the uptake of peptides by this organism are relatively few (Rowlands et al., 1957), in contrast to the numerous studies that have been made with Escherichia coli (Payne, 1968; Payne \& Gilvarg, 1968; Barak \& Gilvarg, 1975).

\section{METHODS}

Organisms. Bacillus subtilis A14 was described by Rogers et al. (1965). Staphylococcus aureus NCTC 6571 and a bacilysin-resistant mutant of this organism were as described by Kenig et al. (1976).

Reagents. Except where otherwise specified all optically active amino acids and peptide residues were of the L-configuration. Glycylglycine was from Hopkin \& Williams, trityrosine was from Miles-Yeda and triornithine was a gift from Dr Z. Barak, Princeton University, U.S.A. Other peptides and also phenylalanine and D-cycloserine were from Sigma and other amino acids were from BDH. Chloramphenicol was from Boehringer. Anticapsin was a gift from Eli Lilly. 


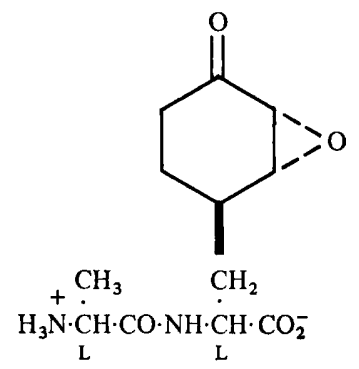

Glycyl[U.-14 $\mathrm{C}]$ phenylalanine $\left(21 \mathrm{mCi} \mathrm{mmol}{ }^{-1}\right),\left[1-{ }^{14} \mathrm{C}\right]$ glycylphenylalanine $\left(16.4 \mathrm{mCi} \mathrm{mmol}^{-1}\right),\left[1-^{14} \mathrm{C}\right]-$ glycylglycine $\left(18 \mathrm{mCi} \mathrm{mmol}^{-1}\right)$ and $\left[\mathrm{U}^{-14} \mathrm{C}\right]$ tyrosine $\left(483 \mathrm{mCi} \mathrm{mmol}^{-1}\right)$ were from The Radiochemical Centre, Amersham. Before use, these peptides were diluted with the corresponding unlabelled peptides to reduce the specific radioactivities to $2 \cdot 0 \mathrm{mCi} \mathrm{mmol}{ }^{-1}$ and the $\left[\mathrm{U}-{ }^{14} \mathrm{C}\right]$ tyrosine was similarly diluted to $26 \mathrm{mCi} \mathrm{mmol}^{-1}$. Alanyl[U-14 $\mathrm{C}]$ tyrosine $\left(0.2 \mathrm{mCi} \mathrm{mmol}^{-1}\right)$ was kindly synthesized by Dr J. J. Usher and was used without dilution.

Production and isolation of bacilysin. The method used for the production of bacilysin was that of Walker \& Abraham (1970), except for the following modifications. For growth of B. subtilis A14 the ferric citrate solution was sterilized separately by filtration (Oxoid membrane filters; pore size $0.45 \mu \mathrm{m}$ ) and added to the autoclaved basal medium to give a final concentration of $150 \mathrm{mg} \mathrm{l}^{-1}$. The sucrose concentration was $10.3 \mathrm{~g} \mathrm{l}^{-1}$ and was obtained by final addition of $30 \mathrm{ml}$ sterile sucrose solution $\left(342 \mathrm{~g} \mathrm{l}^{-1}\right)$ per 1 medium. The organism was grown in the above medium at $27^{\circ} \mathrm{C}$ in 151 batches in a LHE/1000 fermerter (L. H. Engineering, Stoke Poges, Bucks.). The inoculum for each batch was provided by $4 \times 100 \mathrm{ml}$ cultures grown at $27^{\circ} \mathrm{C}$ for $24 \mathrm{~h}$ in the same medium from $0.2 \mathrm{ml}$ of a spore suspension of B. subtilis A14 in $500 \mathrm{ml}$ Erlenmeyer flasks on a rotary shaker $\left(160 \mathrm{rev} . \mathrm{min}^{-1}\right)$. The air flow in the fermenter cultures was $101 \mathrm{~min}^{-1}$ and the rate of stirring was 750 rev. $\mathrm{min}^{-1}$, MS Silicone A (BDH) being used as an antifoam reagent. Cultures were harvested when their absorbance (after 10-fold dilution) had reached 0.4 in a Spekker absorptiometer (Adam Hilger) with a neutral-grey filter (H508) and a $1.5 \mathrm{~cm}$ path length.

Cultures grown under these conditions yielded 100 units bacilysin $\mathrm{ml}^{-1}$ when assayed by the hole-plate method (Kenig \& Abraham, 1976). In earlier experiments (Walker \& Abraham, 1970) the yield had not exceeded 35 units $\mathrm{ml}^{-1}$.

Purification of bacilysin by the procedure of Walker \& Abraham (1970) yielded a product with an activity of about 250 units $\mathrm{mg}^{-1}$.

Media. Kloos liquid and agar media were as described by Kenig et al. (1976). Brain-heart infusion medium and glucose-containing minimal medium (full minimal medium) were as described by Kenig \& Abraham (1976). The latter medium without glucose is henceforth referred to as washing medium.

Preparation of suspensions of $S$. aureus. For studies of peptide and amino acid transport, S. aureus was grown at $37^{\circ} \mathrm{C}$ in $100 \mathrm{ml}$ brain-heart infusion medium in $500 \mathrm{ml}$ Erlenmeyer flasks on a rotary shaker (160 rev. $\min ^{-1}, 5 \mathrm{~cm}$ throw). When the absorbance of the culture was about 7 the bacteria were harvested by centrifugation $(1500 \mathrm{~g}, 10 \mathrm{~min}$ ), washed by suspension in $20 \mathrm{ml}$ washing medium and recentrifugation, and finally suspended in full minimal medium containing chloramphenicol $\left(100 \mu \mathrm{g} \mathrm{ml}^{-1}\right)$ to give an absorbance of 3.9 in a Spekker absorptiometer with $1.5 \mathrm{~cm}$ path length, corresponsing to a bacterial dry weight of $1 \cdot 1 \mathrm{mg} \mathrm{ml}^{-1}$. In a few later experiments glucose was omitted from the suspension medium.

Uptake of ${ }^{14} \mathrm{C}$ from labelled compounds. The method was similar to that of Britten \& McClure (1962) unless otherwise stated. Samples $(1 \mathrm{ml})$ of suspension of $S$. aureus were places in test tubes $(5 \times 1.1 \mathrm{~cm})$ in a reciprocal shaker (one complete movement per second) in a water bath at $37^{\circ} \mathrm{C}$. A known amount of labelled compound was added to each tube in $0.1 \mathrm{ml}$ water and the solutions were mixed. After predetermined times $1 \mathrm{ml}$ samples of the cell suspensions (bacterial dry wt $1 \mathrm{mg}$ ) were removed from separate tubes with a stop-syringe and each sample was expelled on to the surface of a Millipore filter (type HA, pore size $0.45 \mu \mathrm{m}$, $25 \mathrm{~mm}$ diam.) in a Millipore 1225 manifold sampling system coupled to an oil pump.

After filtration the bacteria were washed with washing medium, transferred on the filter to a scintillation vial, and mixed with $9 \mathrm{ml}$ water-miscible scintillation fluid (Bruno \& Christian, 1960). Radioactivity was measured in a Nuclear Chicago Unilux 11A scintillation spectrometer, with a counting efficiency for ${ }^{14} \mathrm{C}$ of $81 \%$. Control experiments were done with known concentrations of labelled compound and with suspensions of $S$. aureus that had been heated in a boiling water bath for $30 \mathrm{~min}$.

In some experiments, in which a considerable proportion of the added ${ }^{14} \mathrm{C}$ was taken up by the bacteria, the loss of radioactivity from the extracellular fluid was also determined. 
Extraction of peptides and amino acids from $S$. aureus. After incubation of suspensions of $S$. aureus with peptides and filtration as described above, the filter and bacteria were added to $10 \mathrm{ml} 75 \%(\mathrm{v} / \mathrm{v})$ ethanol at $70^{\circ} \mathrm{C}$. After filtration through a Millipore filter (pore size $0.45 \mu \mathrm{m}$ ) the extract was evaporated to dryness in vacuo and the residue was taken up in 50 or $100 \mu \mathrm{l}$ water for analysis by electrophoresis on paper.

Estimation of peptidase activity. Extracts of $S$. aureus were prepared as described by Kenig et al. (1976). Protein was determined by a biuret method (Goa, 1953) with bovine serum albumin (BDH) as a standard. The extract was dialysed for $2 \mathrm{~d}$ at $4{ }^{\circ} \mathrm{C}$ against $0.04 \%(\mathrm{w} / \mathrm{v}) \mathrm{NH}_{4} \mathrm{HCO}_{3}$ after a preliminary experiment had indicated that dialysis did not result in a significant loss of peptidase activity with Ala-Tyr or (Gly) ${ }_{2}$ as substrate. For semi-quantitative estimation of peptidase activity, $0.1 \mathrm{ml}$ of a peptide solution (20 mM) was added to a mixture of the dialysed extract $(0.2 \mathrm{ml}$, containing $3 \mathrm{mg}$ protein) and $16.7 \mathrm{~mm}$-Sörensen's phosphate buffer, $\mathrm{pH} 7.0(0.7 \mathrm{ml})$ at $37^{\circ} \mathrm{C}$. Immediately after addition of the peptide and at intervals thereafter, samples $(5 \mu \mathrm{l})$ of the mixture were applied to spots $(5 \mu \mathrm{l})$ of $10 \%(\mathrm{v} / \mathrm{v})$ acetic acid on Whatman no. 1 paper (Waley \& Watson, 1954). To separate unchanged peptide from its constituent amino acids, electrophoresis on paper at $\mathrm{pH} 1.8$ (for $40 \mathrm{~min}$ ) and $\mathrm{pH} 4.5$ (for $1.5 \mathrm{~h}$ ) was then carried out at $70 \mathrm{~V} \mathrm{~cm}^{-1}$ as described by Smith et al. (1967). Peptides and amino acids were visualized by a cadmium-ninhydrin dip (Heilmann et al., 1957). After use of a radioactive peptide the paper was cut into segments $(1 \mathrm{~cm} \times 2.5 \mathrm{~cm}$ wide) and each segment was immersed in water-miscible scintillation fluid $(3 \mathrm{ml})$ for counting.

Amino acid analysis. In some experiments the amino acid and peptide content of solutions was determined with an LKB 4101 amino acid analyser. Tetraalanine was eluted at a position close to that of proline, and trialanine was close to valine.

Estimation of ${ }^{14} \mathrm{CO}_{2}$ produced in bacterial suspension. Solutions $(0.4 \mathrm{ml})$ of $\left[{ }^{14} \mathrm{C}\right] \mathrm{Gly}-\mathrm{Phe}$ or $\mathrm{Gly}-\left[{ }^{14} \mathrm{C}\right] \mathrm{Phe}$ (each 1 and $4 \mathrm{~mm}$ ) were placed in test tubes $(6.0 \times 1.5 \mathrm{~cm}$ ) sealed with rubber stoppers (Suba-Stopper, Gallenkamp). Samples (3.6 ml) of the bacterial suspensions (pH 6.8) were added through a syringe needle and two similar needles were used to enable air to be bubbled through the suspension at $37^{\circ} \mathrm{C}$ and then into Carbo-sorb (7.5 ml, Packard Instrument Co.) contained in a scintillation vial. After the absorption of ${ }^{14} \mathrm{CO}_{2}$, Permafluor V (9 ml, Packard Instrument Co.) was added and the sample was counted. The efficiency of counting was $66 \%$. The radioactivity of the filtrate from the bacterial suspension indicated that more than $90 \%$ of the ${ }^{14} \mathrm{CO}_{2}$ produced was absorbed in the Carbo-sorb under the conditions used.

Preparation of fractions of $S$. aureus labelled from $\left[{ }^{14} \mathrm{C}\right] \mathrm{Gly}$-Phe. Bacterial suspensions $(9 \mathrm{ml})$, with or without $\mathrm{D}$-cycloserine $\left(200 \mu \mathrm{g} \mathrm{ml}^{-1}\right)$, were incubated at $37^{\circ} \mathrm{C}$ for $30 \mathrm{~min}$ and then $\left[{ }^{14} \mathrm{C}\right] \mathrm{Gly}-\mathrm{Phe}(1 \mathrm{ml}, 1.0 \mathrm{~mm})$ was added. At intervals duplicate samples $(1.0 \mathrm{ml})$ were removed, filtered under pressure through Millipore filters (pore size $0.45 \mu \mathrm{m})$, and the bacteria were washed with washing medium $(2 \times 5 \mathrm{ml})$. The filters were then transferred to $5 \mathrm{ml}$ cold $10 \%(\mathrm{w} / \mathrm{v})$ trichloroacetic acid (TCA) and stored overnight at $4{ }^{\circ} \mathrm{C}$. These filters were then placed on fresh filters and the supernatant solution was filtered through them. Samples $(1 \mathrm{ml})$ of the filtrates were counted in $9 \mathrm{ml}$ water-miscible scintillation fluid (efficiency of counting $72 \%$ ). The TCA-insoluble material was washed on the filters with water $(2 \times 5 \mathrm{ml})$ and counted similarly. The two fractions accounted for $93 \%$ of the radioactivity of the bacteria.

Preparation of ${ }^{14} \mathrm{C}$-labelled bacterial walls. The method used was that of Park \& Hancock (1960) as described by Boothby et al. (1971), but with minor modifications. Bacterial suspensions (1 ml) in full minimal medium, which had been incubated with $\left[{ }^{14} \mathrm{C}\right] \mathrm{Gly}$-Phe $\left(100 \mu_{\mathrm{M}}\right)$ for $20 \mathrm{~min}$ at $37^{\circ} \mathrm{C}$, were added to $10 \mathrm{ml}$ $10 \%(\mathrm{w} / \mathrm{v}) \mathrm{TCA}$ at $4{ }^{\circ} \mathrm{C}$ in screw-capped Universal bottles. After storage overnight at $4{ }^{\circ} \mathrm{C}$ the samples were heated in a water bath at $90^{\circ} \mathrm{C}$ for $20 \mathrm{~min}$, cooled and then filtered under pressure through glass-fibre filters (Whatman GF/C, $2.5 \mathrm{~cm}$ diam.). The filters were washed successively with $10 \%(\mathrm{w} / \mathrm{v}) \mathrm{TCA}(4 \mathrm{ml})$, water $(2 \times 4 \mathrm{ml}), 75 \%(\mathrm{v} / \mathrm{v})$ ethanol $(2 \times 4 \mathrm{ml})$, water $(4 \mathrm{ml})$ and Sörensen's $\mathrm{Na}^{+} / \mathrm{K}^{+}$phosphate buffer, pH $8.0(4 \mathrm{ml})$. They were then transferred to solutions of trypsin $\left(2.5 \mathrm{ml}, 1 \mathrm{mg} \mathrm{ml}^{-1}\right.$ in the same buffer) in $25 \mathrm{ml}$ beakers and incubated at $37^{\circ} \mathrm{C}$ for $3 \mathrm{~h}$ with occasional shaking. The filters were placed on fresh filters and after filtration and washing with water $(2 \times 4 \mathrm{ml})$ their radioactivities were determined in $9 \mathrm{ml}$ water-miscible scintillation fluid. The counting efficiency was $78 \%$.

\section{RESULTS}

Uptake and hydrolysis of peptides by S. aureus NCTC 6571 and a bacilysin-resistant mutant

Initial uptake by bacterial suspensions. At $37^{\circ} \mathrm{C}$ the initial rate of uptake of radioactivity from $50 \mu \mathrm{M}$-Gly- $\left[{ }^{14} \mathrm{C}\right] \mathrm{Phe}$ by $S$. aureus NCTC 6571 was rapid and reached a maximum after about 2 min (Fig. 1). Uptake by the bacilysin-resistant mutant did not differ significantly from that obtained with a control containing heat-killed organisms of strain NCTC 6571. Similar results were obtained with Ala- $\left[{ }^{14} \mathrm{C}\right] \mathrm{Tyr}$.

On the assumption that the radioactivity of the bacteria after a $30 \mathrm{~s}$ incubation period 


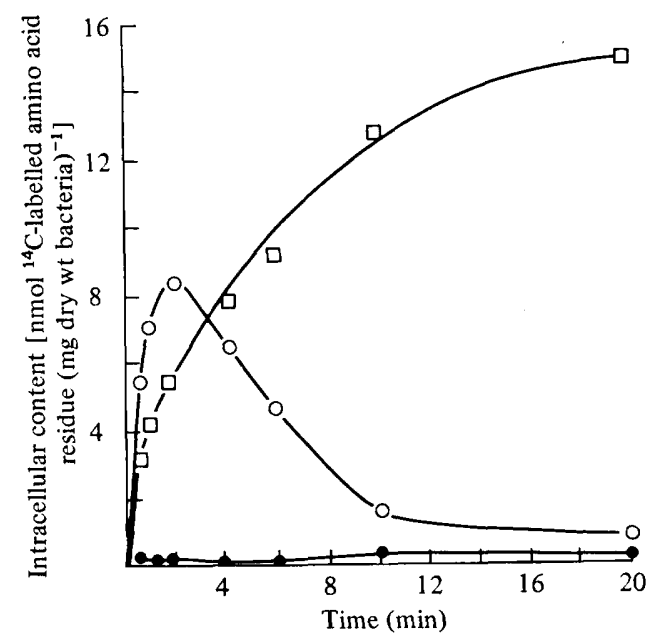

Fig. 1

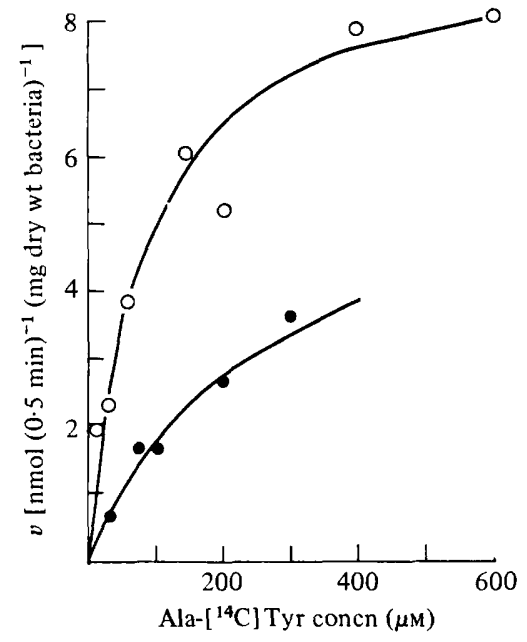

Fig. 2

Fig. 1. Intracellular radioactivity in two strains of $S$. aureus during transport of radioactive dipeptides. Radioactivity from Gly-[U- $\left.{ }^{14} \mathrm{C}\right] \mathrm{Phe}$ in strain NCTC 6571 (O) and a bacilysin-resistant mutant of this strain $(O)$; radioactivity from $\left[1-{ }^{14} \mathrm{C}\right] \mathrm{Gly}$-Phe in strain NCTC $6571(\square)$. The initial concentration of peptides was $50 \mu \mathrm{M}$.

Fig. 2. Effect of bacilysin on the initial rate of uptake of ${ }^{14} \mathrm{C}$ from Ala-[U-14 $\left.\mathrm{C}\right] \mathrm{Tyr}$ by $S$. aureus NCTC 6571 . Rate $(v)$, determined from the uptake after $0.5 \mathrm{~min}$, in the absence $(O)$ or in the presence (O) of bacilysin (initially $400 \mu \mathrm{M}$ ). The curves fitted to the experimental values were calculated on the assumption that the uptake followed Michaelis-Menten kinetics with $K_{\mathrm{m}} 82 \mu \mathrm{M}$ and $V_{\max }$ $9.2 \mathrm{nmol}(0.5 \mathrm{~min})^{-1}\left(\mathrm{mg}\right.$ dry wt bacteria) ${ }^{-1}$ in the absence of bacilysin and an apparent $K_{\mathrm{m}} 280 \mu \mathrm{M}$ and $V_{\max } 6.5 \mathrm{nmol}(0.5 \mathrm{~min})^{-1}(\mathrm{mg} \text { dry wt bacteria) })^{-1}$ in its presence (Eisenthal \& Cornish-Bowden, 1974).

provided a measure of the initial rate of uptake of the peptide, this rate increased almost linearly with the concentration of Ala- $\left[{ }^{14} \mathrm{C}\right] \mathrm{Tyr}$ within the range 1 to $10 \mu \mathrm{M}$. With concentrations of 25 to $600 \mu \mathrm{M}$, the rate increased as shown in Fig. 2 and a Lineweaver-Burk plot of the data indicated that the initial uptake of ${ }^{14} \mathrm{C}$ followed Michaelis-Menten kinetics. Direct linear plots (Eisenthal \& Cornish-Bowden, 1974) from three such sets of data gave a $K_{\mathrm{m}}$ of $77 \pm 10 \mu \mathrm{M}$ and a $V_{\max }$ of $19 \pm 9 \mathrm{nmol}(0.5 \mathrm{~min})^{-1}(\mathrm{mg} \text { dry wt bacteria })^{-1}$.

A similar experiment with $\left[{ }^{14} \mathrm{C}\right]$ tyrosine gave a considerably lower value for $K_{\mathrm{m}}$ (about $10 \mu \mathrm{M})$ and also a lower value for $V_{\max }$ [about $0.75 \mathrm{nmol}(0.5 \mathrm{~min})^{-1}(\mathrm{mg} \text { dry wt bacteria })^{-1}$ ]. But, in contrast to the behaviour of Ala-Tyr, the uptake of tyrosine by the bacilysin-resistant strain did not differ significantly from that by strain 6571 . The $K_{\mathrm{m}}$ value obtained for Gly$\left.{ }^{[14} \mathrm{C}\right] \mathrm{Phe}(304 \mu \mathrm{M})$ and the $V_{\max }$ value $\left[28 \mathrm{nmol}(0.5 \mathrm{~min})^{-1}(\mathrm{mg} \text { dry wt bacteria })^{-1}\right]$ with strain 6571 were both higher than the corresponding values for Ala- $\left[{ }^{14} \mathrm{C}\right] \mathrm{Tyr}$.

At $10{ }^{\circ} \mathrm{C}$ the initial rate of uptake of ${ }^{14} \mathrm{C}$ from Ala- $\left[{ }^{14} \mathrm{C}\right] \mathrm{Tyr}$ was only $1.5 \%$ of that at $37{ }^{\circ} \mathrm{C}$. The uptake of ${ }^{14} \mathrm{C}$ from $\left[{ }^{14} \mathrm{C}\right] \mathrm{Gly}$-Phe and from $\left[{ }^{14} \mathrm{C}\right]$ tyrosine was virtually abolished by prior incubation of the bacterial suspension for $30 \mathrm{~min}$ with $5 \mathrm{~mm}$-p-nitrophenol, although the bacteria remained viable after this treatment. But the initial rates of uptake were not noticeably affected by the omission of glucose from the suspension medium.

The initial rate of uptake by strain 6571 of ${ }^{14} \mathrm{C}$ from Ala- $\left[{ }^{14} \mathrm{C}\right] \mathrm{Tyr}$ at $37{ }^{\circ} \mathrm{C}$ decreased in the presence of bacilysin (Fig. 2). A Lineweaver-Burk plot indicated that inhibition of the uptake of the labelled dipeptide was competitive and from a direct linear plot (Eisenthal \& Cornish-Bowden, 1974) a value of $165 \mu \mathrm{M}$ was calculated for the apparent $K_{\mathrm{i}}$ of bacilysin. A variety of dipeptides and tripeptides also inhibited the uptake of ${ }^{14} \mathrm{C}$ from Ala- $\left[{ }^{14} \mathrm{C}\right] \mathrm{Tyr}$ 


\section{Table 1. Inhibition of uptake of ${ }^{14}$ C-labelled dipeptides by $S$. aureus NCTC 6571}

The initial concentrations of Ala- $\left[\mathrm{U}_{-}{ }^{14} \mathrm{C}\right] \mathrm{Tyr}$ and $\left[1-{ }^{14} \mathrm{C}\right](\mathrm{Gly})_{2}$ were $100 \mu_{\mathrm{M}}$ and the concentrations of unlabelled peptides and amino acids were $1 \mathrm{~mm}$. The initial uptake of ${ }^{14} \mathrm{C}$ was measured after $0.5 \mathrm{~min}$ as described in Methods. In most cases the results represent the average values from three experiments. The typical maximum deviation from the average was $\pm 6 \%$. Figures in parentheses have been calculated from measured $K_{\mathrm{m}}$ values on the assumption that Michaelis-Menten kinetics were followed and that inhibition was competitive.

\begin{tabular}{lcc} 
& \multicolumn{2}{c}{$\begin{array}{c}\text { Inhibition (\%) of initial uptake of } \\
\text { Inhibitor }\end{array} \overbrace{}^{\left.\text {Ala- }{ }^{14} \mathrm{C}\right] \mathrm{Cr} \text { Tyr }}$} \\
Ala-Tyr & $83(85)$ & {$\left[{ }^{14} \mathrm{C}\right](\mathrm{Gly})_{2}$} \\
Gly-Phe & $72(59)$ & $81(99)$ \\
(Gly) & $39(26)$ & $43(43)$ \\
Bacilysin & $76(73)$ & $74(85)$ \\
Gly-Leu & 83 & - \\
(Gly) & 40 & 49 \\
(Ala) & 99 & 74 \\
Gly-Phe-Ala & 73 & 60 \\
(Tyr) & 86 & 83 \\
Ala & - & $<10$ \\
Phe & - & $<10$ \\
Anticapsin & - & $<10$
\end{tabular}

- , Not determined.

(Table 1). All the peptides tested, with the exception of (Gly) ${ }_{2}$ and (Gly) $)_{3}$, appeared to compete with the labelled dipeptide for transport on approximately equal terms.

The relatively poor inhibitory effect of $(\mathrm{Gly})_{2}$ and $(\mathrm{Gly})_{3}$ on the transport of Ala- $\left[{ }^{14} \mathrm{C}\right] \mathrm{Tyr}$ was paralleled by the ability of different di- and tripeptides to inhibit the uptake of ${ }^{14} \mathrm{C}$ from $\left[{ }^{14} \mathrm{C}\right](\mathrm{Gly})_{2}$ (Table 1). Unlabelled $(\mathrm{Gly})_{2}$ and $(\mathrm{Gly})_{3}$ were poorer inhibitors of uptake than were Ala-Tyr, Gly-Phe and bacilysin. Free alanine, phenylalanine and anticapsin were ineffective.

$\left[{ }^{14} \mathrm{C}\right](\mathrm{Gly})_{2}$ also differed in its behaviour from Ala- $\left[{ }^{14} \mathrm{C}\right] \mathrm{Tyr}$ and $\mathrm{Gly}-\left[{ }^{14} \mathrm{C}\right] \mathrm{Phe}$ in that it was taken up by the bacilysin-resistant strain of $S$. aureus. Its initial rate of uptake by the mutant (but not by strain 6571) appeared to increase linearly with concentration up to $2.5 \mathrm{mM}$. At a peptide concentration of $200 \mu \mathrm{M}$ the rate with the resistant mutant was about $18 \%$ of that as observed with strain 6571 .

Hydrolysis of peptides and excretion of amino acids. The amount of ${ }^{14} \mathrm{C}$ from $\mathrm{Gly}-\left[{ }^{14} \mathrm{C}\right] \mathrm{Phe}$ accumulated by $S$. aureus NCTC 6571 in suspension at $37^{\circ} \mathrm{C}$ reached a maximum within $2 \mathrm{~min}$, but more than $80 \%$ of this ${ }^{14} \mathrm{C}$ was lost from the bacteria during the following $10 \mathrm{~min}$ (Fig. 1). A similar result was obtained with Ala- $\left[{ }^{14} \mathrm{C}\right] \mathrm{Tyr}$. A variable loss of ${ }^{14} \mathrm{C}$ from the bacteria was also observed after the uptake of $\left[{ }^{14} \mathrm{C}\right]$ tyrosine.

Electrophoresis on paper of extracts of $S$. aureus which had taken up Gly-Phe and AlaTyr (labelled in their aromatic amino acid residues) showed that the ${ }^{14} \mathrm{C}$ in the bacteria was associated mainly with free phenylalanine and tyrosine, respectively, within $30 \mathrm{~s}$ of the addition of the peptides to the suspension. At this time, radioactive dipeptide, but no radioactive amino acid, was detected in the extracellular fluid, i.e. in the filtrate from the suspension. However, increasing amounts of labelled amino acid appeared in the extracellular fluid after 2 to $4 \mathrm{~min}$ and after 20 to $30 \mathrm{~min}$ all the ${ }^{14} \mathrm{C}$ in the filtrate was associated with free phenylalanine or tyrosine.

In contrast to the loss of radioactivity from $S$. aureus 6571 which rapidly followed the accumulation of ${ }^{14} \mathrm{C}$ from Gly- $\left[{ }^{14} \mathrm{C}\right] \mathrm{Phe}$, accumulation of ${ }^{14} \mathrm{C}$ from $\left[{ }^{14} \mathrm{C}\right] \mathrm{Gly}$-Phe continued during $20 \mathrm{~min}$ (Fig. 1). This finding and those described above show that Gly-Phe and Ala-Tyr continued to be taken up by the bacteria while the phenylalanine and tyrosine, 


\section{Table 2. Peptidase activity of cell extract of $S$. aureus NCTC 6571}

Peptides ( $2 \mathrm{~mm}$ ) were incubated with cell extract for various times at $37^{\circ} \mathrm{C}$. The products were visualized with cadmium-ninhydrin after electrophoresis of samples $(5 \mu \mathrm{l})$ at $\mathrm{pH} 1.8$ or, with $(\mathrm{Ala})_{2},(\mathrm{Gly})_{2}$ and Phe-(Gly) $)_{2}$ only, at $\mathrm{pH} \mathrm{4.5}$. The intensity of spots at zero time is denoted by +++ . Spots that were just visible are denoted by + , which indicates that only about $5 \%$ of the original peptide remained; - , indicates that no spot could be seen. Phe-(Gly) $)_{2}$ was hydrolysed to Phe and $(\mathrm{Gly})_{2}$, but other peptides yielded only their constituent amino acids.

Peptide remaining after time (min):

\begin{tabular}{|c|c|c|c|c|c|}
\hline Peptide & 2 & 4 & 6 & 10 & 20 \\
\hline Bacilysin & +++ & ++ & ++ & ++ & + \\
\hline Ala-Tyr & + & - & - & - & - \\
\hline$(\mathrm{Ala})_{2}$ & $+t$ & + & - & - & - \\
\hline$(\mathrm{Ala})_{3}$ & ++ & + & + & - & - \\
\hline Gly-Tyr & ++ & + & + & - & - \\
\hline Gly-Phe & ++ & ++ & ++ & + & \pm \\
\hline$(\text { Gly })_{2}$ & ++ & $\begin{array}{l}++ \\
++t\end{array}$ & $+t+$ & +++ & +++ \\
\hline $\begin{array}{l}\text { (Gly) })_{2} \text {-Phe } \\
\text { Phe-(Gly) }\end{array}$ & $\begin{array}{l}+++ \\
+++\end{array}$ & $\begin{array}{l}+++ \\
+++\end{array}$ & $\begin{array}{c}+++ \\
++\end{array}$ & $\begin{array}{c}+++ \\
+\end{array}$ & $\begin{array}{c}+t \\
-\end{array}$ \\
\hline$(\mathrm{Tyr})_{3}$ & +++ & ++ & ++ & + & \pm \\
\hline $\begin{array}{l}(\mathrm{Ala})_{4} \\
(\mathrm{Orn})_{3}\end{array}$ & $\begin{array}{l}+++ \\
+++\end{array}$ & $\begin{array}{l}++t \\
+t+\end{array}$ & ++ & ++ & $\begin{array}{c}t \\
+t+\end{array}$ \\
\hline & & & & +++ & \\
\hline
\end{tabular}

respectively, that they yielded on hydrolysis was being extruded into the extracellular medium.

The hydrolysis of (Gly) $)_{2}$ in $S$. aureus 6571 appeared to be much less rapid than that of Gly-Phe, since bacteria that had been incubated for 20 min with $\left[{ }^{14} \mathrm{C}\right](\mathrm{Gly})_{2}(125 \mu \mathrm{M})$ yielded an extract containing approximately equal amounts of radioactivity in the dipeptide and glycine. A semi-quantitative estimation of the hydrolysis of a series of peptides ( $2 \mathrm{mM})$ by a cell extract of $S$. aureus 6571 showed that Ala-Tyr, (Ala) $)_{2},(\mathrm{Ala})_{3}$ and Gly-Tyr were hydrolysed almost completely $(>95 \%)$ in 2 to $5 \mathrm{~min}$ under the conditions used, and Gly-Phe was hydrolysed in $10 \mathrm{~min}$. Bacilysin and (Ala) $)_{4}$ were largely hydrolysed in $20 \mathrm{~min}$, but in this time no hydrolysis of $(\mathrm{Gly})_{2},(\mathrm{Gly})_{2}$-Phe and (Orn $)_{3}$ was detected (Table 2).

Despite its hydrolysis by cell extracts (Ala $)_{4}(1 \mathrm{mM})$ did not undergo detectable metabolism in suspensions of $S$. aureus 6571 at $37^{\circ} \mathrm{C}$ during $1 \mathrm{~h}$, as judged from the results of analysis in the amino acid analyser of a filtrate from the suspension. Virtually all the added (Ala) was found unchanged in the filtrate. On the other hand, (Ala) $)_{2}(1 \mathrm{mM})$ was completely metabolized under similar conditions and only free alanine was found in the filtrate, whilst $(\mathrm{Ala})_{3}(1 \mathrm{mM})$ was partially $(55 \%)$ metabolized. However, (Ala) $)_{3}$, like (Ala $)_{4}$ was not hydrolysed by a suspension of the bacilysin-resistant mutant.

\section{Metabolism of glycine from $\left[{ }^{14} \mathrm{C}\right]$ Gly-Phe}

Incorporation of glycine into bacterial walls. Staphylococci which had accumulated ${ }^{14} \mathrm{C}$ on incubation for $45 \mathrm{~min}$ with $\left[{ }^{14} \mathrm{C}\right]$ Gly-Phe $(50 \mu \mathrm{M})$ (Fig. 1) and had then been filtered and washed lost no radioactivity when resuspended in fresh medium for $90 \mathrm{~min}$. The possibility that glycine formed by hydrolysis of the dipeptide had been incorporated into protein could be discounted, since the bacterial suspensions contained chloramphenicol and since virtually no ${ }^{14} \mathrm{C}$ was found in material insoluble in $10 \%(\mathrm{w} / \mathrm{v})$ TCA from bacteria that had been incubated for $20 \mathrm{~min}$ with Ala- $\left[{ }^{14} \mathrm{C}\right] \mathrm{Tyr}$ or Gly- $\left[{ }^{14} \mathrm{C}\right] \mathrm{Phe}$ (each $100 \mu \mathrm{M}$ ). However, when $\left[{ }^{14} \mathrm{C}\right] \mathrm{Gly}-\mathrm{Phe}$ was added to a suspension of $S$. aureus 6571 most of the ${ }^{14} \mathrm{C}$ accumulated by the bacteria appeared in a TCA-insoluble fraction within 2 min (Fig. 3) and after $20 \mathrm{~min}$ the radioactivity of a similar fraction accounted for $18 \%$ of the total in the peptide added. Walls isolated from organisms incubated for $20 \mathrm{~min}$ lost $82 \%$ of their ${ }^{14} \mathrm{C}$ on digestion with lysozyme $\left(2 \mathrm{mg} \mathrm{ml}^{-1}\right)$ for $8 \mathrm{~h}$.

The addition of D-cycloserine $\left(200 \mu \mathrm{g} \mathrm{ml}^{-1}\right)$ to the suspension of $S$. aureus to inhibit wall 


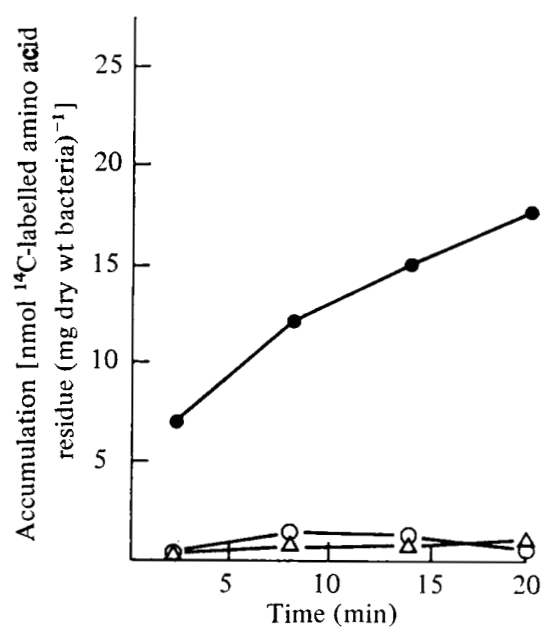

Fig. 3

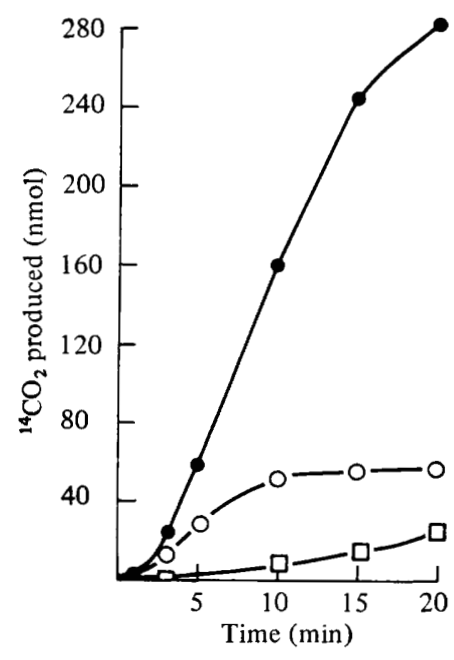

Fig. 4

Fig. 3. Accumulation of $\left[{ }^{14} \mathrm{C}\right]$ glycine residues from $\left[1-{ }^{14} \mathrm{C}\right] \mathrm{Gly}-\mathrm{Phe}$ in bacterial walls. $\left[{ }^{14} \mathrm{C}\right] \mathrm{Gly}-\mathrm{Phe}$ $(100 \mu \mathrm{M})$ was incubated with suspensions of $S$. aureus NCTC 6571. Radioactivity of the TCAinsoluble fraction from bacteria incubated with $(\triangle)$ or without $(\bigcirc)$ D-cycloserine $\left(200 \mu \mathrm{g} \mathrm{ml}^{-1}\right)$; radioactivity of the TCA-soluble fraction from bacteria incubated without D-cycloserine $(O)$.

Fig. 4. Production of ${ }^{14} \mathrm{CO}_{2}$ in suspensions of $S$. aureus $\mathrm{NCTC} 6571$ from $\left[1-{ }^{14} \mathrm{C}\right] \mathrm{Gly}-\mathrm{Phe}$ and Gly-[U-14 C]Phe. Each suspension $(1 \mathrm{ml})$ contained bacteria equivalent to $1 \mathrm{mg}$ dry wt. 0 , $\left[{ }^{14} \mathrm{C}\right] \mathrm{Gly}-$ Phe $(400 \mu \mathrm{M}) ; O,\left[{ }^{14} \mathrm{C}\right]$ Gly-Phe $(100 \mu \mathrm{M}) ; \square$, Gly- $\left[{ }^{14} \mathrm{C}\right] \mathrm{Phe}(100$ or $400 \mu \mathrm{M})$. For the conversion of the radioactivity of $\mathrm{CO}_{2}$ from Gly- $\left[{ }^{14} \mathrm{C}\right] \mathrm{Phe}$ to $\mathrm{nmol}^{14} \mathrm{CO}_{2}$ it was assumed that $\mathrm{CO}_{2}$ was derived only from $\mathrm{C}-1$ of the phenylalanine; the values for ${ }^{14} \mathrm{CO}_{2}$ in this case are thus maximum values.

synthesis reduced the incorporation of ${ }^{14} \mathrm{C}$ from $\left[{ }^{14} \mathrm{C}\right] \mathrm{Gly}$-Phe into the TCA-insoluble fraction of the bacteria to a very low level, but produced no marked increase in the amount of ${ }^{14} \mathrm{C}$ in the TCA-soluble fraction. Electrophoresis of a sample of the filtrates from such a bacterial suspension revealed that it contained considerably more $\left[{ }^{14} \mathrm{C}\right]$ glycine than did a control filtrate from a bacterial suspension to which no D-cycloserine had been added.

Degradation of glycine from $\left[{ }^{14} \mathrm{C}\right] \mathrm{Gly}$-Phe and $\left[{ }^{14} \mathrm{C}\right](\mathrm{Gly})_{2}$. In addition to its incorporation into the bacterial wall, the $\left[{ }^{14} \mathrm{C}\right]$ glycine formed from 100 or $400 \mu \mathrm{M}-\left[{ }^{14} \mathrm{C}\right] \mathrm{Gly}-\mathrm{Phe}$ in $S$. aureus 6571 was degraded to ${ }^{14} \mathrm{CO}_{2}$ (Fig. 4). The ${ }^{14} \mathrm{CO}_{2}$ produced within $15 \mathrm{~min}$ accounted for more than $50 \%$ of the total ${ }^{14} \mathrm{C}$ added. In contrast, the amount of ${ }^{14} \mathrm{CO}_{2}$ liberated from Gly- $\left[{ }^{14} \mathrm{C}\right]$ Phe under similar conditions was relatively small and did not increase when the initial concentration of the peptide was raised (Fig. 4).

A consequence of the loss of radioactivity as ${ }^{14} \mathrm{CO}_{2}$ from $\left[{ }^{14} \mathrm{C}\right]$ glycine is that the values obtained for the uptake of $\left[{ }^{14} \mathrm{C}\right] \mathrm{Gly}$-Phe by $S$. aureus 6571 were lower than the true values. However, since the loss of ${ }^{14} \mathrm{CO}_{2}$ increased with the concentration of this peptide it was possible for apparent rates of uptake to be approximately consistent with MichaelisMenten kinetics. The degradation of glycine in the bacteria could thus account for the finding that the apparent value of $V_{\max }$ for the uptake of $\left[{ }^{14} \mathrm{C}\right] \mathrm{Gly}$-Phe was $8.9 \mathrm{nmol}$ $(0.5 \mathrm{~min})^{-1}$ (mg dry wt bacteria) $)^{-1}$ and the $K_{\mathrm{m}}$ was $91 \mu \mathrm{M}$, whereas the corresponding values obtained for Gly- $\left[{ }^{14} \mathrm{C}\right] \mathrm{Phe}$ were $28 \mathrm{nmol}(0.5 \mathrm{~min})^{-1}\left(\mathrm{mg}\right.$ dry wt bacteria) ${ }^{-1}$ and $304 \mu \mathrm{M}$.

The measured $K_{\mathrm{m}}$ for the uptake of $\left[{ }^{14} \mathrm{C}\right](\mathrm{Gly})_{2}(1 \cdot 2 \mathrm{mM})$ was more than ten times that for $\left[{ }^{14} \mathrm{C}\right] \mathrm{Gly}-\mathrm{Phe}$ and nearly four times that for Gly- $\left[{ }^{14} \mathrm{C}\right] \mathrm{Phe}$. Since the hydrolysis of $(\mathrm{Gly})_{2}$ was relatively slow the measured $K_{\mathrm{m}}$ for this dipeptide may be not much less than the true $K_{\mathrm{m}}$. The high $K_{\mathrm{m}}$ is consistent with the finding that (Gly) $)_{2}$ was less effective than the other dipeptides tested as an inhibitor of dipeptide uptake (Table 1). 


\section{DISCUSSION}

The rapid metabolism of Gly-Phe and other peptides by $S$. aureus in non-growing suspensions complicated attempts to demonstrate directly that such peptides were transported intact into the bacteria. However, the radioactivity of bacteria that had been incubated for $0.5 \mathrm{~min}$ with Gly- $\left[{ }^{14} \mathrm{C}\right] \mathrm{Phe}$ and Ala- $\left[{ }^{14} \mathrm{C}\right] \mathrm{Tyr}$ appeared to provide a reliable measure of the total ${ }^{14} \mathrm{C}$ taken up. The finding that the values of $V_{\max }$ and $K_{\mathrm{m}}$ obtained for the uptake of the labelled tyrosine moiety of Ala-Tyr were much larger than those for free tyrosine thus indicated that the mechanism of uptake did not involve external hydrolysis of the peptide by a membrane-bound peptidase and subsequent capture of the liberated amino acids by amino acid transport systems. But whether peptidase action has a rôle in the mechanism of transport is not clear.

The high temperature coefficient of the initial rate of uptake of Ala-Tyr and Gly-Phe, the inhibition of uptake by $p$-nitrophenol and the fact that the variation of the rate with peptide concentration could be described by simple Michaelis-Menten kinetics were consistent with an enzyme-like active transport mechanism. Rowlands et al. (1957) reported that the addition of glucose to suspensions of $S$. aureus was necessary for the accumulation of glutamic acid in the bacteria from free glutamic acid or glutamyl peptides in the medium. However, in the present experiments the addition of an external energy source was not required for the transport of Gly-Phe.

The competition of a number of di- and tripeptides with each other and with bacilysin for uptake indicated that all these peptides could share a single transport system in S. aureus, although this system would not necessarily be the only one capable of transporting dipeptides. The continued uptake of Gly-Phe while phenylalanine formed from it by hydrolysis was being released by the bacteria suggests that this release is not a consequence of a failure of an energy source, as appeared to be the case in the transport of L-serine by membrane vesicles of $E$. coli (Konings \& Freese, 1972). The lag before phenylalanine appeared in the extracellular medium suggested that release of this amino acid might only occur after its intracellular concentration had reached a critical level. Whether there is a specific exit mechanism or one that responds to osmotic changes (Britten, 1965) remains unclear.

The results reported here with $S$. aureus 6571 are qualitatively similar to some of those obtained in studies of peptide transport in E. coli (Payne, 1968; Barak \& Gilvarg, 1975; Payne, 1976). (Gly), which was atypical in being taken up, although slowly, by a bacilysinresistant mutant of $S$. aureus 6571 , has been thought to enter $E$. coli by a diffusion process as well as by a saturable transport system (Cowell, 1974). Amino acids formed by intracellular hydrolysis of certain peptides (and also amino acids synthesized de novo) have been found to be released from $E$. coli during peptide transport (Payne \& Bell, 1977a, b, 1979). However, although the oligopeptide transport system of $E$. coli efficiently transports pentapeptides, $S$. aureus 6571 did not take up (Ala) $)_{4}$ at a measurable rate under the conditions used. Whether the ability to transport specific tetrapeptides varies from one strain of $S$. aureus to another remains to be determined. The report of Allen et al. (1978) that trialanyl-1-aminoethylphosphonic acid showed low antibacterial activity against a strain which differed from that used here indicated that some transport of this tetrapeptide occurred.

The present results indicate that the transport of bacilysin into $S$. aureus and the subsequent extrusion of anticapsin into the extracellular fluid (Kenig et al., 1976) are brought about by mechanisms which are responsible for the analogous behaviour of peptides with little or no antibacterial activity, such as Gly-Phe and Ala-Tyr. The application of peptide transport and hydrolysis to the design of antibiotics has been discussed by Diddens \& Zähner (1976), Lichliter et al. (1976), Neuhaus et al. (1977) and Allen et al. (1978).

We wish to thank the Medical Research Council for financial support. 


\section{REFERENCES}

Allen, J. G., Atherton, F. R., Hall, M. J., Hassall, C. H., Holmes, S. W., Lambert, R. W., Nisbet, L. J. \& Ringrose, P. S. (1978). Phosphonopeptides, a new class of synthetic antibacterial agents. Nature, London, 272, 56-58.

BaraK, Z. \& GilvarG, C. (1975). Peptide transport. In Biomembranes, vol. 7, pp. 167-210. Edited by H. Eisenberg, E. Katchalski-Katzir \& L. A. Manson. New York \& London: Plenum Press.

Boothby, D., Daneo-Moore, L. \& Shockman, G. D. (1971). A rapid, quantitative and selective estimation of radioactively labelled peptidoglycan in gram-positive bacteria. Analytical Biochemistry 44, 645-653.

BRITTEN, R. J. (1965). The concentration of small molecules within the microbial cell. Symposia of the Society for General Microbiology 15, 57-88.

Britten, R. J. \& MCClure, F. T. (1962). The amino acid pool in Escherichia coli. Bacteriological Reviews 26, 293-335.

Bruno, G. A. \& Christian, J. E. (1960). Note on suitable solvent systems usable in the liquid scintillation counting of animal tissue. Journal of the American Pharmaceutical Association 49, 560-561.

Cowell, J. L. (1974). Energetics of glycylglycine transport in Escherichia coli. Journal of Bacteriology 120, 139-146.

DIDDENS, H. \& ZÄHNER, H. (1976). On the transport of tripeptide antibiotics in bacteria. European Journal of Biochemistry 66, 11-23.

Eisenthal, R. \& CoRnish-Bowden, A. (1974). The direct linear plot. A new graphical procedure for estimating enzyme kinetic parameters. Biochemical Journal 139, 715-720.

GoA, J. (1953). A micro-biuret method for protein determination: determination of total protein in cerebrospinal fluid. Scandinavian Journal of Clinical and Laboratory Investigation 5, 218-222.

HeilmanN, J., BarRollier, J. \& WATZKe, E. (1957). Beitrage zur Aminosäurebestimmung auf Papierchromatogrammen. Zeitschrift für physiologische Chemie 309, 219-220.

KenIG, M. \& ABRahaM, E. P. (1976). Antimicrobial activities and antagonists of bacilysin and anticapsin. Journal of General Microbiology 94, $37-45$.

Kenig, M., Vandamme, E. \& Abraham, E. P. (1976). The mode of action of bacilysin and anticapsin, and biochemical properties of bacilysin-resistant mutants. Journal of General Microbiology 94, 46-54.

Konings, W. N. \& Freese, E. (1972). Amino acid transport in membrane vesicles of Bacillus subtilis. Journal of Biological Chemistry 247, 2408-2418.

Lichliter, W. D., NAider, F. \& Becker, J. M. (1976). Basis for the design of anticandidal agents from studies of peptide utilization in Candida albicans. Antimicrobial Agents and Chemotherapy 10, 483-490.

Neuhaus, F. C., Goyer, S. \& Neuhaus, D. W. (1977). Growth inhibition of Escherichia coli W by D-norvalyl-D-alanine: an analogue of D-alanine in position 4 of the peptide subunit of peptidoglycan. Antimicrobial Agents and Chemotherapy 11, 638-644.

Neuss, N., Molloy, B. B., ShaH, R. \& DelaHIGUERA, N. (1970). The structure of anticapsin, a new biologically active metabolite of Streptomyces griseoplanus. Biochemical Journal 118, 571-575.

PARK, J. T. \& HANCOCK, R. (1960). A fractionation procedure for studies of the synthesis of cell-wall mucopeptide and other polymers in cells of Staphylococcus aureus. Journal of General Microbiology 22, 249-258.

PAYNE, J. W. (1968). Oligopeptide transport in Escherichia coli. Journal of Biological Chemistry 243, 3394-3403.

PAyne, J. W. (1976). Peptides and micro-organisms. Advances in Microbial Physiology 13, 55-113.

PAYNe, J. W. \& Bell, G. (1977a). The transport and utilization of peptides by Escherichia coli: interrelationships between peptide uptake and amino acid exodus and biosynthesis. FEMS Microbiology Letters 2, 259-262.

PAYNe, J. W. \& Bell, G. (1977b). Substrate interactions during transport of amino acids and peptides by Escherichia coli: relevance to regulation of peptide uptake. FEMS Microbiology Letters 2, 301-304.

Payne, J. W. \& Bell, G. (1979). Direct determination of the properties of peptide transport systems in Escherichia coli using a fluorescent labeling procedure. Journal of Bacteriology 137, 447-455.

Payne, J. W. \& Gilvarg, C. (1968). Size restriction on peptide utilization in Escherichia coli. Journal of Biological Chemistry 243, 6291-6299.

Rogers, H. J., Newton, G. G. F. \& Abraham, E. P. (1965). Production and purification of bacilysin. Biochemical Journal 97, 573-578.

Rowlands, D. A., Gale, E. F., Folkes, J. P. \& MARRIAN, D. H. (1957). The assimilation of amino acids by bacteria. 23. Accumulation of free glutamic acid with Staphylococcus aureus incubated with derivatives of glutamic acid. Biochemical Journal 65, 519-526.

Smith, B., Warren, S. C., Newton, G. G. F. \& AbrahaM, E. P. (1967). Biosynthesis of penicillin $\mathrm{N}$ and cephalosporin C. Biochemical Journal 103, 877-890.

Waley, S. G. \& WAtson, J. (1954). Trypsincatalyzed transpeptidations. Biochemical Journal 57, 529-538.

Walker, J. E. \& Abraham, E. P. (1970). The structure of bacilysin and other products of Bacillus subtilis. Biochemical Journal 118, 563-570. 